Article

\title{
E-Commerce Sales System Based Mobile Android (Case Study: PT.Makmur Cipta Sejahtera)
}

\author{
Agung Kurniawan Toing ${ }^{1}$, Ardie Halim Wijaya ${ }^{2}$, \\ 1, 2 Buddhi Dharma University, Information Systems, Banten, Indonesia
}

\begin{tabular}{l}
\hline SUBMISSION TRACK \\
\hline Received 20 June 2019; \\
Revised 20 July 2019; \\
Accepted 10 September 2019; \\
Available online 20 September 2019 \\
KEYWORDS \\
\hline e-commerce, android, mobile app \\
CORRESPONDENCE \\
E-mail: agungtoing@gmail.com \\
E-mail: ardie.h@gmail.com
\end{tabular}

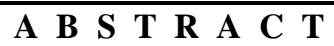

With the passage of the sales process manually which is less efficient and less effective in PT. Makmur Cipta Sejahtera, it needs a program to support the efficiency and effectiveness of the sales process. The process of ordering goods that still use manual methods to use mail order goods, make the authors design and create an Android-based sales program. The research method is done by two methods: analysis of research and data collection methods. Methods of data collection by interview, observation and literature. User needs, among others are able to provide accurate reports, user-friendly and simple interface, capable of showing product details, and how to use that are not complicated. After the design, manufacture, and testing of the program, some conclusions that this program may support the efficiency and effectiveness of the sales process, minimize the opportunities for error, and cost efficiency in terms of paperless. Hopefully this program can be a learning for students who want to take thesis with the title associated with the sale of e-commerce system based on mobile android. I welcome any comments and suggestions for the design of the system is still flawed. then a number of conclusions that this program may support the efficiency and effectiveness of the sales process, to minimize opportunities for error, and cost efficiency in terms of paperless. Hopefully this program can be a learning for students who want to take thesis with the title associated with the sale of e-commerce system based on mobile android. I welcome any comments and suggestions for the design of the system because it still flawed.

\section{INTRODUCTION}

PT. Makmur Cipta Sejahtera is a company engaged in manufacturing. This company is one of the many companies that exist in Indonesia which has a constraint in terms of marketing. The problem faced by PT. Makmur Cipta Sejahtera now is ordering products still use the system that less effective where to order the products should be written in a form in advance by the 
salesman then input by the admin into a computer, which is can cause risk opportunity against error in inputting or manipulation of data and also require a long time to make the process of ordering goods. The absence of the implementation of recording inventories in the information system causing frequent stock-outs can occur even excess supplies that lead the sales process to be disrupted. Listing on the stock card which is less accurate, causing the biased information. Then the identification of problems that can be described as follows:

1. Sell products using leaflets / brochures is something that takes a long time compared to selling products with e-commerce.

2. Many customers are lazy to store leaflets / brochures.

3. The inventory data is not accurate.

1. Planning

Search a wide range of similar research aimed to get an overview of the application process so that it can determine which information systems will be developed.

2. Analysis

Analyze and learn so many things through the results of the data collected to obtain a complete theoretical basis.

3. Design

The process of making a plan to get an application design in accordance with what is desired by the owner.

4. Implementation

Implementation of a system application that was created to ensure that users like the application.

b. Method of collecting data

\section{RESULTS}

PT. Makmur Cipta Sejahtera was established in the middle of 2005. Over time, the company has made changes and improvements in various systems, so that finally evolved into a company that has full integration in the field of furniture. The company is now located at Jl. Daan KM.18 Block A 16, West Jakarta. All of this has
For the formulation of the problem can be described as follows:

1. How to help customers in the sales process to be more efficient?

2. How to assist customers in getting information digitally?

3. How to assist customers in getting accurate information?

From the description of the problem, it made a study entitled "E-Commerce Sales System Based Mobile Android (Case Study: PT. Makmur Cipta Sejahtera)".

\section{RESEARCH METHODOLOGY}

To analyze and make e-commerce sales system based on mobile android PT. Makmur Cipta Sejahtera a research method:

a. Analysis Methods Research

1. Interview

Do the frequently asked questions to obtain information about the data and processes associated with the system is running at the moment.

2. Observation

Direct observation of the organization at the company profile, product, marketing and transaction system conducted to learn the business structure, business processes and corporate policies and information systems that already exist in the company.

3. Literature review

Search and data collection related to the research process to design information systems based ecommerce mobile android.

made PT. Makmur Cipta Sejahtera become one of the leading manufacturers of knockdown furniture in Indonesia. Now PT. Makmur Cipta Sejahtera is facing a problem of lacking effective sales system, so it can affect the progress of the company. With the design of the proposed system application sales are expected to support the sales 
process in the PT. Makmur Cipta Sejahtera. From the interview conducted with managers of PT. Makmur Cipta Sejahtera on the application of e-commerce sales system based on Android, then get some statements that could serve as a reference in making this application. Then the sales system of ecommerce-based android equipped with service features that generate appropriate reports, look simple and attractive, more interactive, featuring prices and menu options are detailed, easy to use and uncomplicated, the history of the order / transaction, may adding new products, promotions, use minimal memory, can update product information. The application of e-commerce sales system android based mobile does not support the features of the product searching and can't make payments in cash or non-cash.

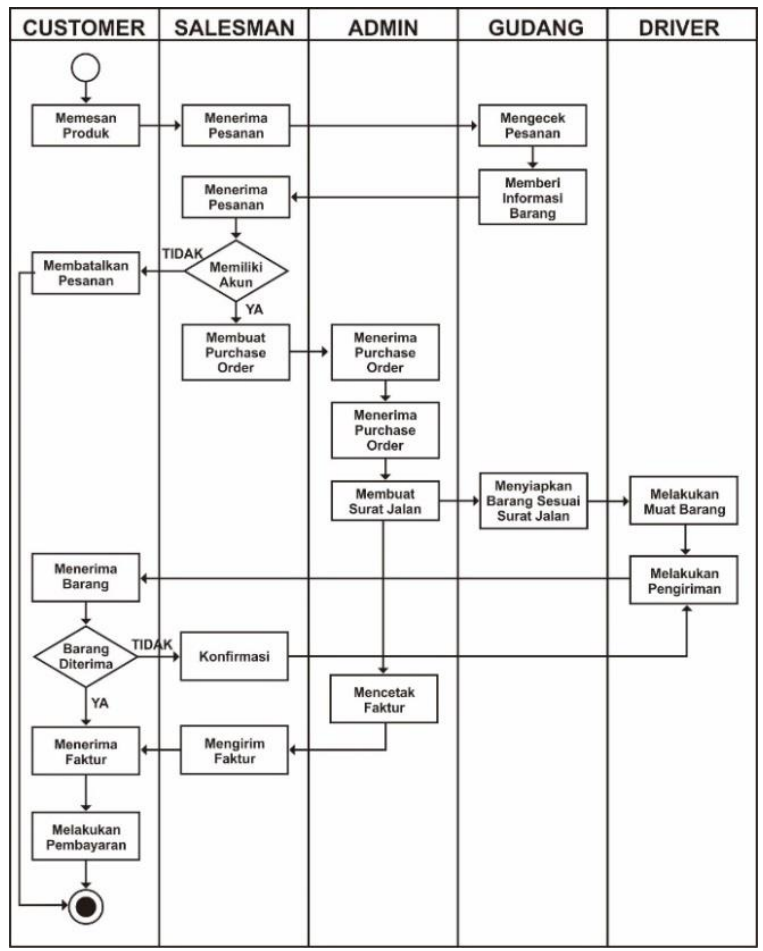

Figure 1: Current Activity Diagram

\section{DISCUSSION}

After the research and know the workflow of the current sales at PT. Makmur Cipta Sejahtera and also know about the problems faced along with alternatives to solving the problem, it can be proposed a design of a system using mobile-based e-commerce android. In this case the application design emphasizes on ordering products online. With the design of the system can be obtained benefit is to improve the effectiveness and efficiency in the company, so that the new system will be run in accordance with the needs in the support business activities and included can expand online sales transactions. Moreover, it can have an impact on the increase in sales of PT. Makmur Cipta Sejahtera itself. The increase was caused by a product that can be viewed online thus become more widespread sales coverage. Picture below is an application of the proposed design:

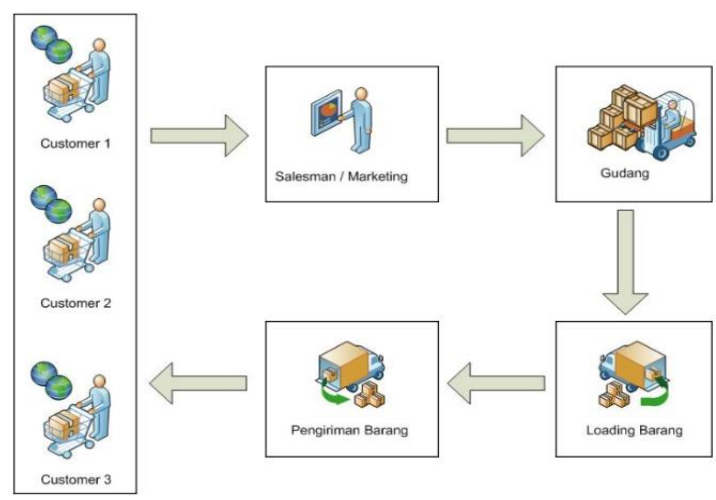

Figure 2: Application Concept Proposal

This is a diagram of the proposed use case for the application of e-commerce sales system based on mobile android PT. Makmur Cipta Sejahtera:

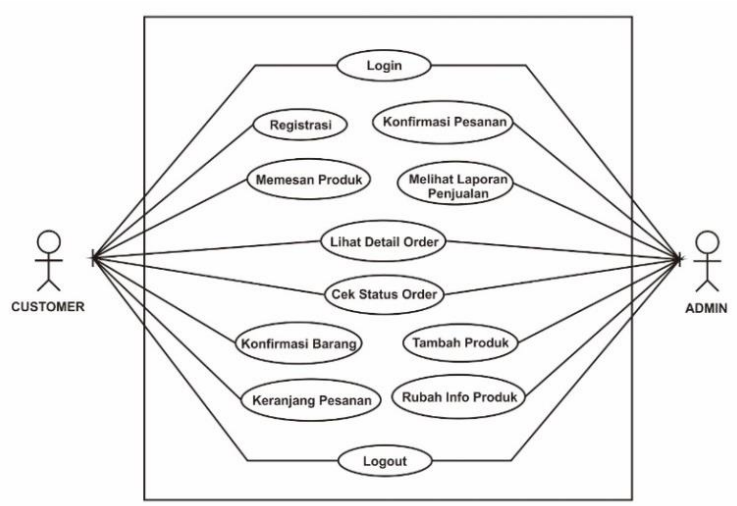

Figure 3: Proposed Use Case Diagram 
This is an activity diagram of the proposed system for the application of e-commerce sales system based on mobile android PT. Makmur Cipta Sejahtera:

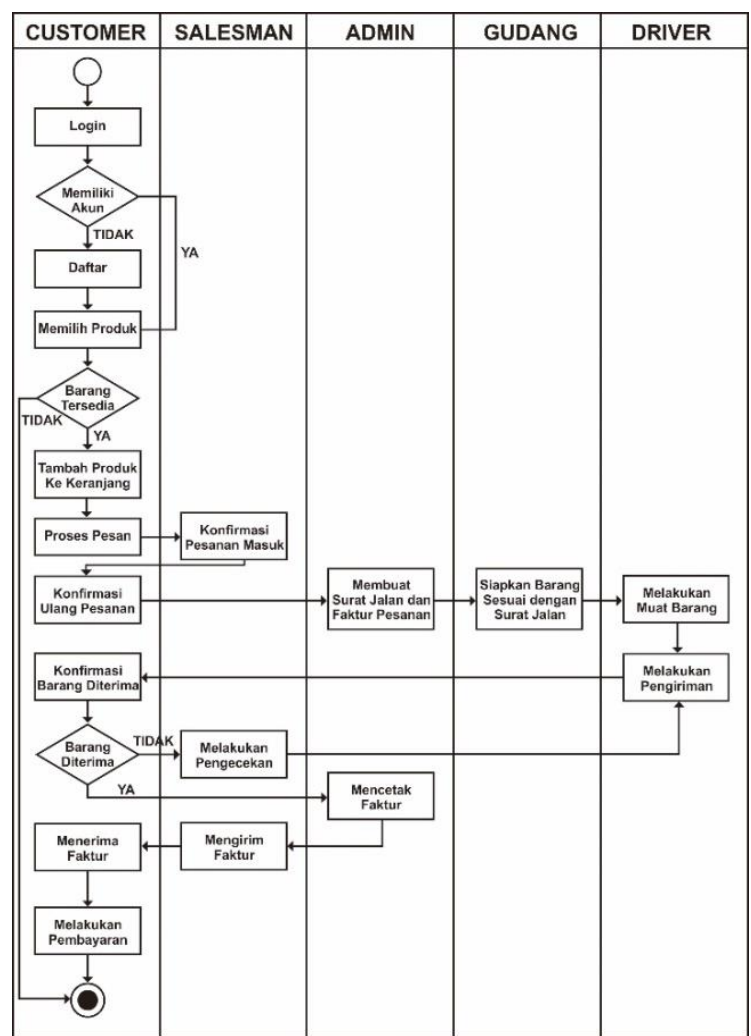

Figure 4: Diagram Activity Proposal

This is the main page view of goods ordering application at PT. Makmur Cipta Sejahtera:

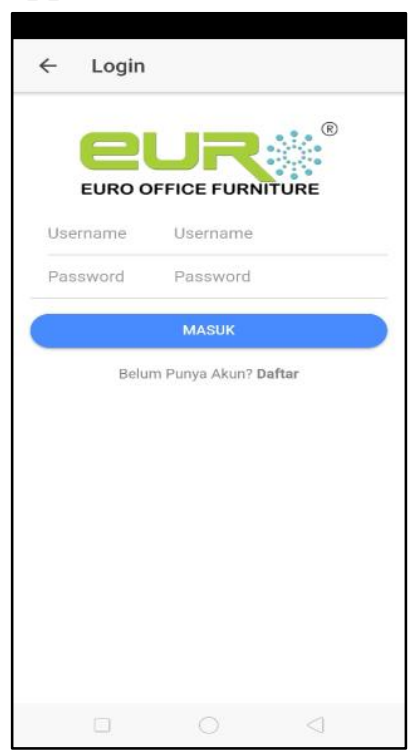

Figure 5: Home Applications
This is a new account registration page display of the goods ordering application at PT. Makmur Cipta Sejahtera:

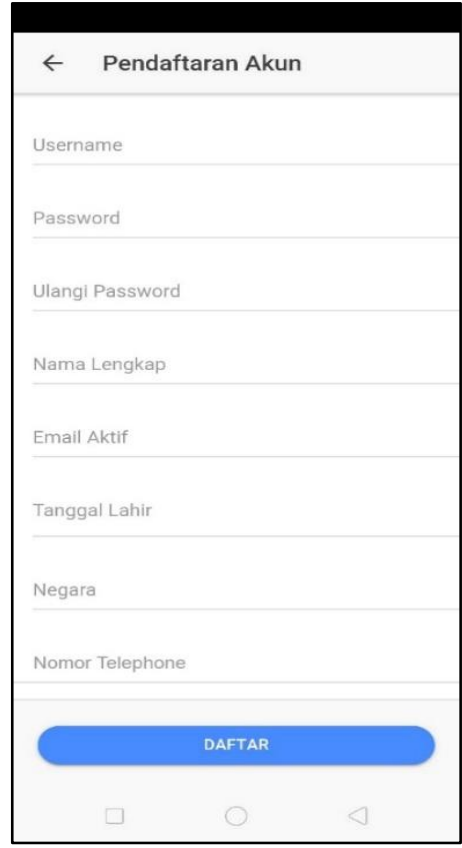

Figure 6: Account Registration page

Here is a view of the user's home of the page goods ordering application at PT. Makmur Cipta Sejahtera:

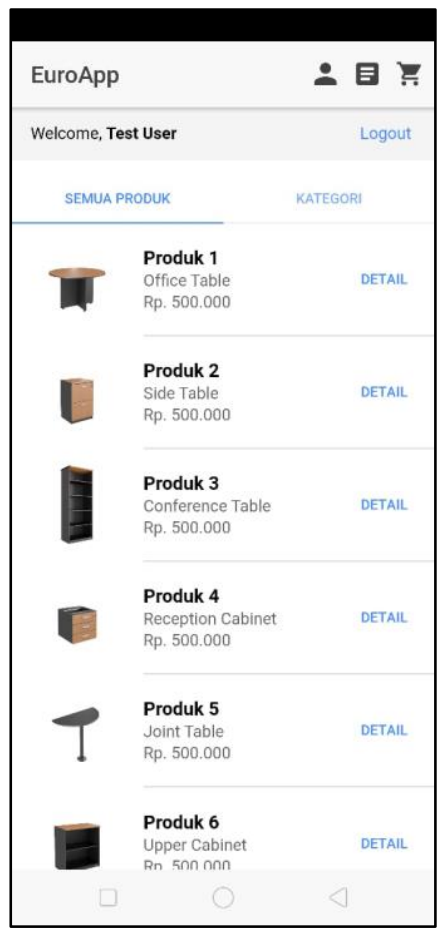

Figure 7: User Home Page 
This is a view of the home page admin of the goods ordering application at PT. Makmur Cipta Sejahtera:

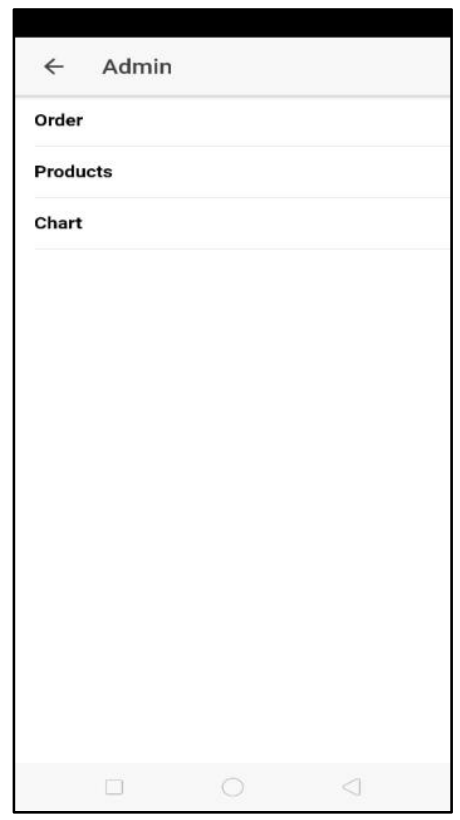

Figure 8: Admin Home page

This is the product detail page display of the goods ordering application at PT. Makmur Cipta Sejahtera:

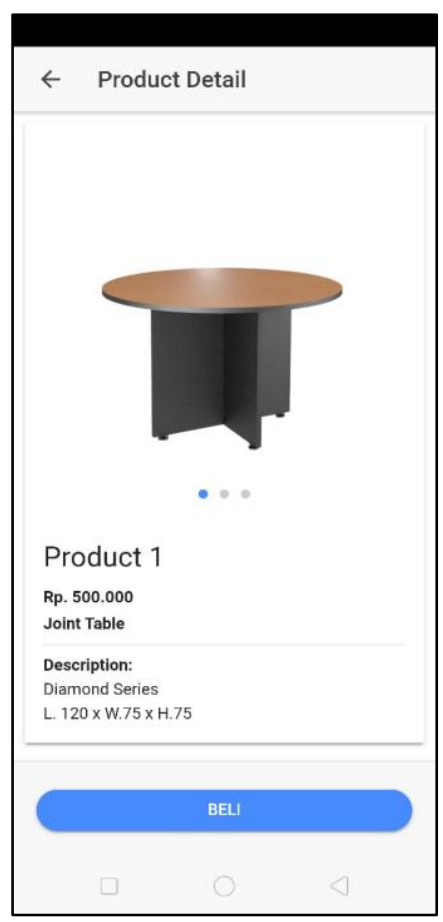

Figure 9: Product Detail Page User
This is a page view shopping cart of the goods ordering application at PT. Makmur Cipta Sejahtera:

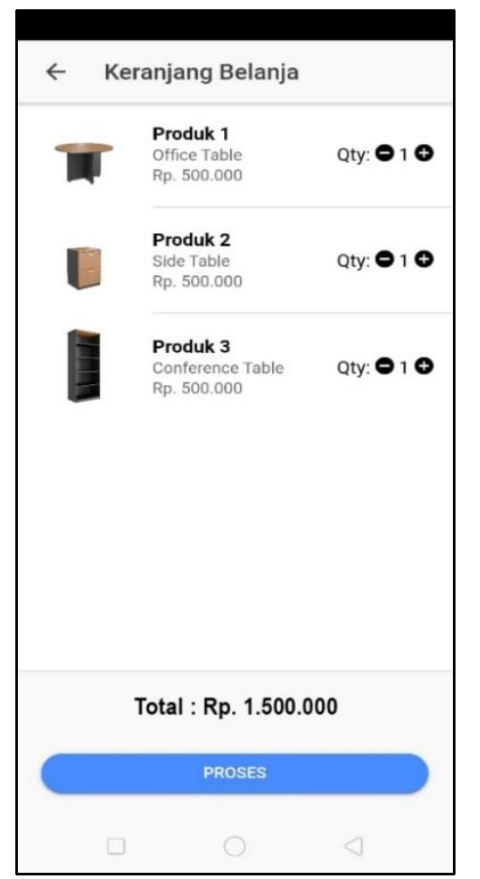

Figure 10: Home Shopping Cart

This is a page view-added products of the goods ordering application at PT. Makmur Cipta Sejahtera:

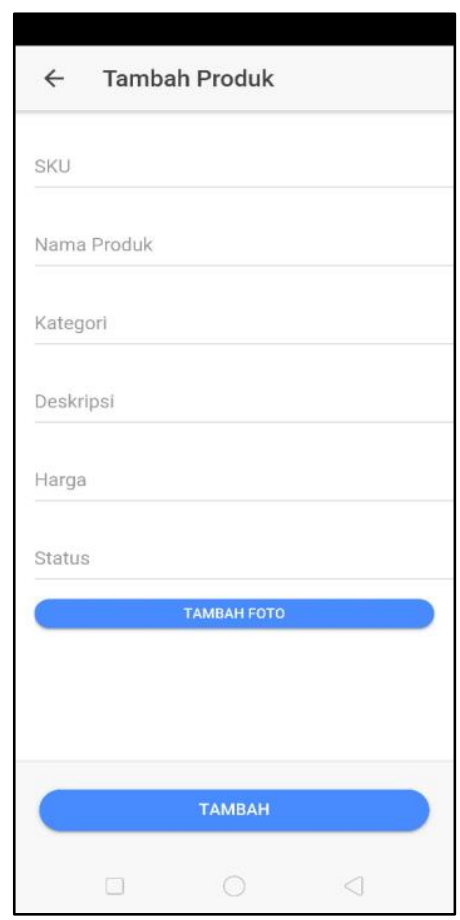

Figure 11: Home Add New Products 
This is a chart of page views of the goods ordering application at PT. Makmur Cipta Sejahtera:

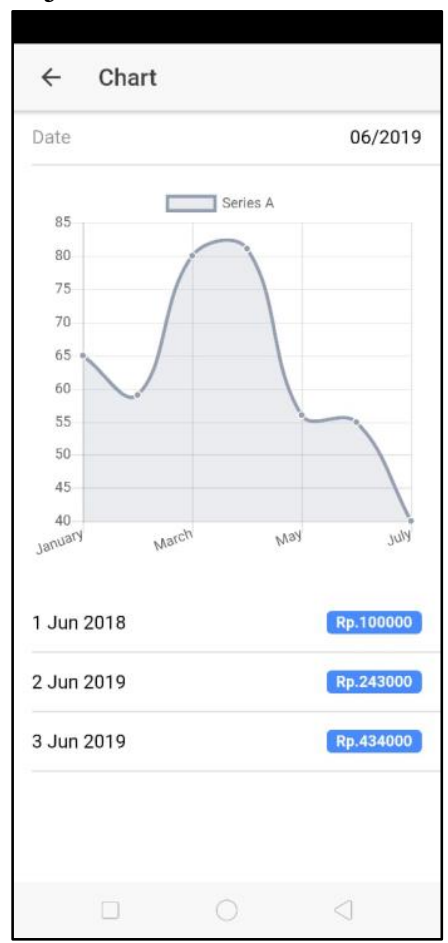

Figure 12: Home Chart

\section{CONCLUSION}

After doing research at PT. Makmur Cipta Sejahtera, then produced an application of e- commerce sales system based on mobile android which is a form of improvement of the system has been running in the company. This application is made in accordance with the request to handle the marketing system, ordering and purchasing which is applied. Based on trials and evaluations that have been done, then the writer can make conclusions as follows:

1) E-commerce sales system android based mobile can support efficiency and effectiveness, as it can facilitate the customer to make a reservation and purchase.

2) E-commerce sales system android based mobile can assist customers in getting information on products marketed.

3) E-commerce sales system android based mobile can help companies to more advanced, and can compete with other companies in the era of digitalization and modern.

\section{REFERENCES}

[1] Hendrayudi, Pengertian Aplikasi, Yogyakarta: Andi, 2009.

[2] J. Wong, Internet Marketing for Beginners, Jakarta: PT. Elex Media Komputindo, 2010.

[3] B. Raharjo, Belajar Otodidak Membuat Database Menggunakan MySQL, Bandung: Abdi Sistematika, 2016.

[4] Sulihati, and Andriyani, "Aplikasi Akademik Online Berbasis Mobile Android Pada Universitas Tama Jagakarsa”, Jurnal Sains dan Teknologi, Vol.11, hh.16., 2016.

[5] B.K. Williams, and S.C. Sawyer, Using Information Technology : A Practical Introduction to Computers \& Communications, New York: McGraw-Hill, 2011.

[6] A.B. Ladjamudin, Analisis dan Desain Sistem Informasi, Yogyakarta: Graha Ilmu, 2013.

[7] F.K. Alexander, Kitab Suci Web Programming, Yogyakarta: Media Komputer, 2011.

[8] C. Dafe, Internet Marketing: Strategy, Implementation and Practice, Jakarta: Printece Hall, 2009.

[9] C. Thomas, and B. Carolyn, Database Systems a Practical Approach to Design, Management Fifth Edition, Boston: Pearson Education, 2010.

[10] Deitel, Java:How to Program. Boston: Pearson Education, 2012.

[11] A. Kadir, Buku Pintar Programmer Pemula PHP, Yogyakarta: Media Komputer, 2013.

[12] S. Mulyani, Metode Analisis dan Perancangan Sistem, Bandung: Abdi Sistematika, 2016. 


\section{BIOGRAPHY}

Agung Kurniawan Toing was born in the city of Tangerang, on 31 August 1995. He was a student of the University of Buddhi Dharma, majored in Information of Technology Management and also an employee of PT. Makmur Cipta Sejahtera.

Ardie Halim Wijaya. Was born in the city of Tangerang, on 28 August 1991. He obtained his bachelor of computer (S.Kom.) at STMIK Buddhi in 2013 and completed his master of computer graduate program (M.Kom.) at University of Budi Luhur in 2016. He was the lecturer and head of Informatics Management study program at University of Buddhi Dharma. 